\title{
Mastektomi pada kambing peranakan etawa (Capra aegagrus hircus)
}

\author{
Gunanti $^{1, *}$, Sus Derthi Widhyari ${ }^{1}$, Selma Laily Nur Afifah ${ }^{2}$, Shavrillia Inovanny Angesti ${ }^{2}$, \\ Intan Khoirunnisa ${ }^{2}$, Irda Khaeriyah ${ }^{2}$, Riana Nurul Maulani ${ }^{2}$, Beata LYL Ayu ${ }^{2}$ \\ ${ }^{1}$ Departemen Klinik, Reproduksi dan Patologi, Fakultas Kedokteran Hewan, IPB University, Bogor \\ ${ }^{2}$ Program Pendidikan Profesi Dokter Hewan, Fakultas Kedokteran Hewan, IPB University, Bogor
}

\begin{abstract}
ABSTRAK: Kambing betina peranakan etawa berumur 3 tahun diperiksa dengan gejala ada pembesaran di kelenjar mamaria. Anamnesis kambing sudah beranak 5 kali, setiap beranak 1-2 ekor dan anaknya selalu mati. Air susu induk tidak keluar walaupun terlihat ada pembesaran kelenjar mamaria. Pemeriksaan klinis menunjukkan ada pembesaran salah satu kelenjar mamaria. Diagnosis kambing tersebut menderita tumor mamaria. Hasil pemeriksaan laboratorium sebelum operasi menunjukkan gambaran hematologi masih dalam keadaan normal meskipun $\mathrm{Hb}$ normal rendah dan platelet rendah. Setelah operasi menunjukkan peningkatan neutrophil, monosit, dan kadar hemoglobin. Operasi masektomi berhasil dengan baik dan kondisi hewan setelah operasi memperlihatkan nafsu makan dan minum baik. Terjadi peningkatan gambaran RBC dan Hb sehingga kambing dilanjutkan perawatan sampai pulih kembali.
\end{abstract}

Kata kunci:

hemogram, mastektomi, operasi, tumor mamaria, kambing peranakan etawa

\section{- PENDAHULUAN}

Tumor pada ambing adalah neoplasma yang berasal dari kelenjar mamaria. Kasus ini jarang terjadi pada ruminansia. Deferensasi diagnosa dari tumor ini adalah mastitis, abses, hematoma, dan kondisi lain. Faktor predisposisi diet, riwayat reproduksi, beban stres, fisiologi umum dan metabolisme. Jenis tumor pada jaringan lunak (kulit) dibedakan menjadi, tumor kulit primer yaitu melanoma dan karsinoma sel skuamosa dan tumor me-tastasis sekunder yaitu limfosarkoma (Mihevc dan Peter 2013).

Mastektomi adalah operasi untuk mengobati kondisi yang melibatkan kelenjar mamaria dan struktur terkait lainnya. Indikasi yang sering digunakan untuk mastektomi adalah mastitis toksik, gangren, abses ambing, kondisi neoplastik, ambing berkembang tanpa kebuntingan, kerusakan parah pada jaringan pendukung ambing (Allen et al. 2008). Mastektomi radikal dilakukan dengan pengangkatan seluruh kelenjar mamaria baik unilateral atau bilateral. Selain itu, hemi-mastektomi juga dapat dilakukan dengan pengangkatan sebagian kelenjar mamaria. Akan tetapi hal ini tidak direkomendasikan karena tidak ada batasan jelas diantara kelenjar mamaria. Komplikasi yang mungkin terjadi adalah perdarahan, potensi syok, infeksi pada area pembedahan, penurunan atau hilangnya produksi susu secara permanen.

Tulisan ini melaporkan penanganan kasus tumor mamaria pada kambing peranakan etawa yang diterapi melalui tindakan mastektomi modifikasi di Divisi Bedah dan Radiologi, Departemen Klinik, Reproduksi dan Patologi, Fakultas Kedokteran Hewan, IPB University.

\section{- KASUS}

Anamnesis, sinyalemen dan status pasien: terdapat pembesaran kelenjar mammaria yang berlangsung kronis (Gambar 1). Kambing betina peranakan etawa berumur 3 tahun dengan bobot badan $35 \mathrm{~kg}$ dan body condition score 2,5. Pemeriksaan klinis: a) sehari sebelum operasi: frekuensi jantung $96 \mathrm{x} /$ menit, frekuensi napas $28 \mathrm{x} /$ menit, suhu tubuh $38,9^{\circ} \mathrm{C}$, mukosa berwarna rose, capillary refill time (CRT) $<3$ detik, limfonodus tidak ada kelainan. b) pemeriksaan sesaat sebelum operasi: frekuensi jantung 80 $\mathrm{x} /$ menit, frekuensi napas $15 \mathrm{x} /$ menit, suhu tubuh $40^{\circ} \mathrm{C}$, mukosa berwarna rose, CRT $<3$ detik, dan tidak terdapat kelainan pada limfonodus.

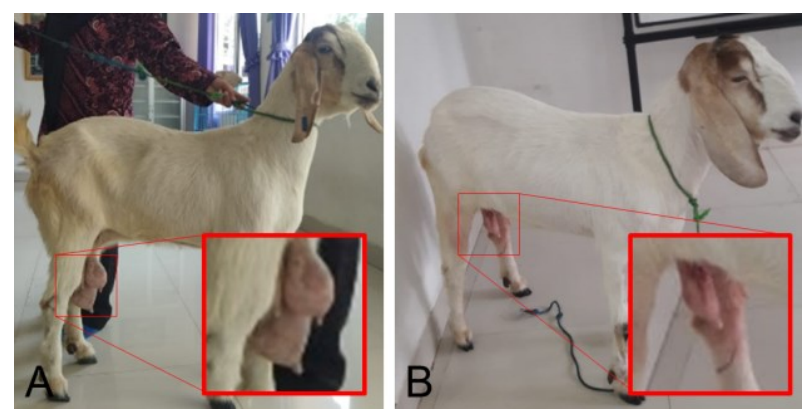

Gambar 1. Kambing peranakan etawa. (A) Sebelum dan (B) sesudah operasi. Tanda panah $=$ tumor mamaria.

Diterima: 21-02-2020 | Direvisi: 25-03-2020 | Disetujui: 30-03-2020

(C) 2020 CC-BY-SA. Ini adalah artikel Open Access yang didistribusikan berdasarkan ketentuan dari Creative Commons Attribution ShareAlike 4.0 International License (https://creativecommons.org/licenses/by-sa/4.0/). 
Temuan klinis: dua kuartir ambing mengalami pembesaran dengan ukuran yang berbeda dan konsistensi lunak, salah satu kuartir tidak ada perubahan ukuran, dan salah satu kuartir membesar. Pemeriksaan penunjang: hematologi lengkap. Diagnosis: tumor kelenjar mamaria. Deferensasi diagnosis: mastitis, abses, dan hematoma.

\section{- HASIL DAN PEMBAHASAN}

Kejadian tumor mamaria jarang terjadi pada hewan herbivora. Tumor mamaria umumnya terjadi pada ruminansia yang berumur tua lebih dari 6 tahun. Hiperesterogenisme sangat erat kaitannya dengan adanya tumor mamari (Mihevc dan Peter 2013).

Pemeriksaan penunjang darah lengkap sebelum operasi secara umum dalam keadaan normal meskipun menunjukkan $\mathrm{Hb}$ normal rendah, platelet rendah, dan MCHC menurun (Tabel 1). Gambaran darah 3 hari setelah operasi menunjukkan jumlah neutrofil dan monosit yang mengalami kenaikan. Menurut McElroy dan Bassett (2010), kambing yang menderita tumor mamaria menunjukkan keadaan fisiologi, nafsu makan, suhu tubuh yang normal. Hal tersebut dapat disebabkan oleh adanya peradangan pada luka akibat tindakan operasi. Tahap inflamasi merupakan salah satu tahapan dari proses persembuhan luka (Purnama et al. 2017).

Hasil hematologi lengkap juga menunjukkan adanya peningkatan kadar hemoglobin setelah operasi (Tabel 1). Suplai darah dan oksigen di dalam tubuh menjadi tidak optimal saat terdapat tumor (Irawan 2015), pada saat tumor tersebut diangkat suplai darah dan oksigen pada tubuh meningkat, sehingga terjadi peningkatan hemoglobin.

Tabel 1. Profil hematologi kambing sebelum dan setelah operasi.

\begin{tabular}{|lccc|}
\hline Parameter & $\begin{array}{c}\text { Sebelum } \\
\text { Operasi }\end{array}$ & $\begin{array}{c}\text { Setelah } \\
\text { Operasi }\end{array}$ & Range Normal \\
\hline RBC & $15,88 \mathrm{M} / \mu \mathrm{L}$ & $18,47 \mathrm{M} / \mu \mathrm{L}$ & $10,32-23,43$ \\
$\mathrm{HCT}$ & $32,1 \%$ & $37,3 \%$ & $22,0-39,0$ \\
$\mathrm{HGB}$ & $8,7 \mathrm{~g} / \mathrm{dL}$ & $9,4 \mathrm{~g} / \mathrm{dL}$ & $8,9-13,8$ \\
MCV & $20,2 \mathrm{fL}$ & $20,2 \mathrm{fL}$ & $14,0-22,3$ \\
MCH & $5,5 \mathrm{pg}$ & $5,1 \mathrm{pg}$ & $5,0-7,0$ \\
MCHC & $27,1 \mathrm{~g} / \mathrm{dL}$ & $25,2 \mathrm{~g} / \mathrm{dL}$ & $32,0-34,0$ \\
WBC & $10,41 \mathrm{~K} / \mu \mathrm{L}$ & $18,07 \mathrm{~K} / \mu \mathrm{L}$ & $6,03-19,58$ \\
$\%$ NEU & $43,5 \%$ & $63,8 \%$ & - \\
$\% \mathrm{LYM}$ & $42,4 \%$ & $25,3 \%$ & - \\
$\% \mathrm{MONO}$ & $3,9 \%$ & $7,1 \%$ & - \\
$\% \mathrm{EOS}$ & $10,1 \%$ & $3,7 \%$ & - \\
$\% \mathrm{BASO}$ & $0,1 \%$ & $0,1 \%$ & - \\
NEU & $4,53 \mathrm{~K} / \mu \mathrm{L}$ & $11,52 \mathrm{~K} / \mu \mathrm{L}$ & $1,72-10,61$ \\
$\mathrm{LYM}$ & $4,41 \mathrm{~K} / \mu \mathrm{L}$ & $4,57 \mathrm{~K} / \mu \mathrm{L}$ & $2,68-11,54$ \\
MONO & $0,41 \mathrm{~K} / \mu \mathrm{L}$ & $1,29 \mathrm{~K} / \mu \mathrm{L}$ & $0,06-0,89$ \\
EOS & $1,05 \mathrm{~K} / \mu \mathrm{L}$ & $0,67 \mathrm{~K} / \mu \mathrm{L}$ & $0,03-1,29$ \\
BASO & $0,01 \mathrm{~K} / \mu \mathrm{L}$ & $0,02 \mathrm{~K} / \mu \mathrm{L}$ & $0,00-0,24$ \\
PLT & $149 \mathrm{~K} / \mu \mathrm{L}$ & $460 \mathrm{~K} / \mu \mathrm{L}$ & $246-912$ \\
MPV & $7,7 \mathrm{fL}$ & $8,4 \mathrm{fL}$ & - \\
\hline
\end{tabular}

Terapi operasi pengangkatan tumor dilakukan dengan metode mastektomi modifikasi. Kambing sebelum operasi dipuasakan dari makan 1x24 jam dan minum 4 jam. Kemudian kambing dianestesi dengan pemberian premedikasi Atropine Sulfat $(0,15 \mathrm{mg} / \mathrm{kg} \mathrm{BB})$ secara subkutan, anastesi umum yaitu kombinasi Ketamin $(5,0 \mathrm{mg} / \mathrm{kg} \mathrm{BB})$ dengan Xylazin $(0,1 \mathrm{mg} / \mathrm{kg} \mathrm{BB})$ secara intramuskular. Setelah itu, anestesi lokal ring block menggunakan Lidokain 2\% (4-6 $\mathrm{mL}$ ) diinjeksikan disekitar lokasi sayatan.

Kambing diposisikan dorsal recumbency di atas meja operasi yang telah diberi under pad dan heating pad untuk menjaga temperatur tubuh. Keempat kakinya difiksasi dengan tali sumbu kompor (simpul tomfool). Operasi diawali dengan insisi kulit berbentuk elips menggunakan scalpel no. 3 di sekeliling bagian dasar glandula mamaria yang akan diangkat. Kulit disayat dan dikuakkan dari jaringan disekitarnya. Hemostasis dilakukan menggunakan electrocauter. Pembuluh darah (arteri dan vena pudenda eksterna, arteri perineal dan pembuluh darah caudal epigastricum yang ada di superfisial) diligasi. Tumor pada kelenjar mamaria dipreparir kemudian diangkat. Penjahitan jaringan subkutis menggunakan benang chromic catgut 3-0 absorbable dengan jahitan continuous. Luka pada kulit ditutup menggunakan jahitan simple menggunakan benang silk 2-0 non-absorbable (Tan et al. 2003).

Pengobatan setelah operasi diberikan antibiotik dan anti radang. Antibiotik Amoxicillin dosis $15 \mathrm{mg} / \mathrm{kg}$ BB diberikan selama 5 hari, Antibiotik topikal menggunakan Gentamicin sulfate dioleskan pada area luka, kemudian ditutup dengan perban. Anti radang Meloxicam single dose $0,5 \mathrm{mg} / \mathrm{kg} \mathrm{BB}$ diberikan secara IV atau SC selama 3 hari.

\section{- SIMPULAN}

Operasi mastektomi berhasil dengan baik. Kondisi hewan setelah operasi memperlihatkan nafsu makan dan minum baik serta terjadi peningkatan gambaran $\mathrm{RBC}$ dan $\mathrm{Hb}$.

\section{- INFORMASI PENULIS}

Penulis untuk Korespondensi

*G: gunanti.soe@gmail.com

Divisi Bedah dan Radiologi, Departemen Klinik, Reproduksi, dan Patologi, Fakultas Kedokteran Hewan, Universitas IPB, Jalan Agatis Kampus IPB Dramaga, Bogor, Jawa Barat, Indonesia.

\section{- PUSTAKA ACUAN}

Allen AJ, Barrington GM, Parish SM. 2008. Physiologic mastectomy via flank laparotomy. Veterinary Clinics of North America: Food Animal Practice. 24(3):511-516.

Irawan A. 2015. Efektivitas kombinasi dutasteride dan teh hijau terhadap perdarahan pada BPH pasca-turp: kajian pengaruhnya terhadap ekspresi hypoxia induced factor 1-alpha (hif $-1 \alpha$ ) \& hematokrit (ht) [tesis]. Semarang (ID): Universitas Diponegoro.

McElroy MC, Bassett HF. 2010. Mammary carcinoma in a ewe. Journal of veterinary diagnostic investigation. 22(6):1006-1007.

Mihevc SP, Peter DO. 2013. Mammary tumors in ruminants. Acta Agriculturae Slovenica. 2(84):102.

Purnama H, Sriwidodo, Ratnawulan S. 2017. Proses penyembuhan dan perawatan luka: Review sistematik. Farmaka. 15(2):251-258.

Tan R, Bell RJW, Dowling BA, Dart AJ. 2003. Suture materials: composition and application in veterinary wound repair. Australian veterinary journal. 81(3): 140-145. 
